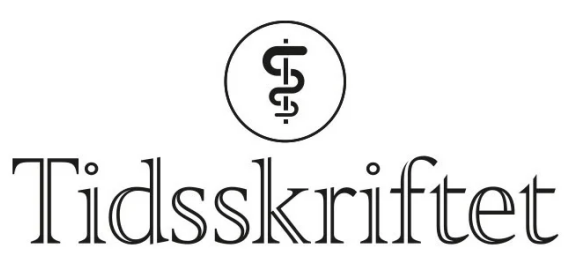

DEN NORSKE LEGEFORENING

\title{
Er konklusjonen pålitelig?
}

\author{
KOMMENTAR
}

\section{FERNANDO BOIX}

fernando.boix@ous-hf.no

Fernando Boix er seniorforsker.

Forfatteren har ikke oppgitt noen interessekonflikter.

Man finner i artikkelen en høy korrelasjon mellom de variablene som har vært brukt som prediktorvariabler. Dette innebærer en betydelig multikollinearitet (graden av lineær sammenheng mellom flere forklaringsvariabler i en multippel regresjonsmodell). Multikollinearitet er et godt kjent problem i lineær regresjonsanalyse. Multikollinearitet kan øke variansen til koeffisientestimatene og påvirke den statistiske signifikansen av uavhengige variabler (1).

Koeffisientestimatene blir da ustabile og følsomme for mindre endringer i modellen. Dette innebærer at valg av egnede prediktorer basert på deres statistiske signifikans blir problematisk og kan føre til falske konklusjoner.

Under diskusjonen, drøfter forfatterne mulige svakheter med studien, men ikke multikollinearitet. Dersom problemer med multikollinearitet ikke har blitt riktig adressert er ikke konklusjonene som trekkes pålitelige nok. Da må man være forsiktig med anbefalinger til bruk i helsepolitikkøyemed.

\section{LITTERATUR}

1. The problem of multicollinearity. I: Understanding Regression Analysis. Boston, MA: Springer, 1997. https://link.springer.com/chapter/10.1007\%2F978-0-585-25657-3_37. Lest 26.3.2021.

Publisert:3. mai 2021. Tidsskr Nor Legeforen. DOI: 10.4045/tidsskr.21.03o6

(C) Tidsskrift for Den norske legeforening 2023. Lastet ned fra tidsskriftet.no 26. april 2023. 